\title{
Nonoverlapping expression patterns of ALK1 and ALK5 reveal distinct roles of each receptor in vascular development
}

\author{
Tsugio Seki*, Kwon-Ho Hong* and S Paul Oh \\ Department of Physiology and Functional Genomics, University of Florida College of Medicine, Gainesville, \\ FL, USA
}

\begin{abstract}
Transforming growth factor $\beta$ (TGF- $\beta$ ) transmits signals through a heterotetrameric cell-surface complex of type II (TGFBR2) and type I (activin receptor-like kinase 5, ALK5; TGFBR1) serine/threonine kinase receptors, as well as Smad2/3. We have previously shown that another type I receptor, ALK1 (ACVRL1), can also mediate TGF- $\beta$ signals via BMP-activated Smads in vascular endothelial cells (ECs). Our group and others have proposed the hypothesis that two TGF- $\beta$ signaling pathways via ALK1 and ALK5 in vascular ECs may play a balancing role for controlling the proliferation and migration of ECs during angiogenesis. To address in vivo roles of this balance in vascular development, we have created a knockin mouse line that carries a lacZ reporter in the Alk5 gene locus (Alk $5^{\text {lacz }}$ ). Throughout development, a well-defined, nonubiquitous expression pattern of Alk5 expression was observed in multiple tissues, and organs. Overall, a high level of Alk5 expression was found in perichondria, periostea, and the mesenchymal layers underlying epithelia in the kidney, lung, and gallbladder. In blood vessels, contrasting to predominant Alk1 expression in arterial endothelium, Alk5 expression was localized in the medial and adventitial layers of blood vessels, but was undetectable in the intimal layer. In addition, although Alk5-null embryos exhibit a defect in the formation of vascular smooth muscle layers, the lumens of blood vessels are generated properly, which stands in contrast to the severe dilation of the vascular lumens in Alk1-null mice. These mutually exclusive expression patterns of Alk1 and Alk5 in blood vessels, as well as the undisturbed formation of the vascular lumens in Alk5-null embryos, suggest that each type I receptor has its own unique functions in vascular development. The $A / k 5^{\text {lacz }}$ mice will be a valuable resource in identifying the in vivo cellular targets of TGF- $\beta$ family signals mediated by Alk5, both during embryonic development as well as in diverse pathological conditions.
\end{abstract}

Laboratory Investigation (2006) 86, 116-129. doi:10.1038/labinvest.3700376; published online 12 December 2005

Keywords: ALK1; ALK5; TGF- $\beta$; angiogenesis; endothelium; smooth muscle cells

The transforming growth factor- $\beta$ (TGF- $\beta$ ) family members include TGF- $\beta$ s, bone morphogenic proteins (BMPs), activins, and growth and differentiation factors (GDFs). These signaling proteins play critical roles in a wide variety of biological processes, including proliferation, differentiation, pattern formation, and apoptosis. The TGF- $\beta$ family cytokines exert their effects by binding to the heteromeric complexes of two types of transmembrane serine/threonine kinase receptors. ${ }^{1-3}$ Type II receptors function primarily as binding receptors.

Correspondence: Dr SP Oh, PhD, Department of Physiology and Functional Genomics, University of Florida, 1600 SW Archer Rd, D5-36, Gainesville, FL 32610, USA.

E-mail: ohp@phys.med.ufl.edu

*These authors contributed equally to this work

Received 10 October 2005; revised and accepted 7 November 2005; published online 12 December 2005
Upon binding their ligands, the type II receptors associate with and phosphorylate type I receptors which, in turn, activate downstream Smad proteins.

Eight Smad protein have been identified in mammals., ${ }^{2,4}$ The activated type I receptor phosphorylates receptor-regulated Smads (R-Smads). RSmads then form a complex with a common partner Smad4 (Co-Smad), and enter into the nucleus. Once there, the Smad complex interacts with diverse transcriptional coactivators or corepressors, according to genetic makeup and cellular contexts. Depending on which R-Smad is utilized, TGF- $\beta$ signaling can be largely separated into two pathways: BMP signals via Smad1, 5, or 8, and activin/ TGF- $\beta$ signals via Smad 2 or 3 .

For more than 27 known TGF- $\beta$ family ligands, only five type II receptors and seven type I receptors have been identified, ${ }^{5}$ indicating that each receptor mediates multiple signals. Biochemical studies have 
determined that activin receptor-like kinase 3 (ALK3; BMPR1) and ALK6 (BMPR1B) interact primarily with the BMP type II receptor (BMPR2), and mediate BMP subfamily signals; and that activin type II receptors (ACVR2A and ACVR2B) utilize ALK2 (ACVR1), ALK4 (ACVR1B), and ALK7 (ACVRL1C) depending on their interacting ligands including activins (INHBA, INHBB, INHBC, and INHBE), Nodal, BMP7, and GDF11. ${ }^{6-8}$ Activin receptor-like kinase 5 (ALK5) (T $\beta$ RI; TGFBR1) has been shown to interact with the TGF- $\beta$ type II receptor (T $\beta$ RII; TGFBR2), and to mediate TGF- $\beta$ subfamily signals. ${ }^{5}$ Recent studies have implicated that ALK5 may also mediate other TGF- $\beta$ family signals, such as GDF8 and GDF11.9,10

Activin receptor-like kinase 1 (ALK1) (ACVRL1) was initially considered to be an orphan receptor, because its binding specificities were obscured. ${ }^{11}$ We have previously shown that ALK1 in human umbilical vein endothelial cells (HUVECs) binds to TGF- $\beta 1 .{ }^{12}$ In contrast to the signal transduction of ALK5 via Smad2/3, activated ALK1 phosphorylates Smad1/5/8. ${ }^{12,13}$ This observation led us to postulate that both ALK1 and ALK5 mediate the TGF- $\beta$ signal in endothelial cells (ECs) and that one of the two type I receptors is activated depending on the cellular context, such as TGF- $\beta$ concentration. ${ }^{12}$ Based on the vascular dilation/fusion and molecular characterization of $A l k 1^{-1-}$ embryos, we suggested that ALK1 may play an important role in the transition of ECs to the resolution phase, whereas ALK5 may stimulate their activation phase during angiogenesis. ${ }^{12}$

Two independent groups investigated this hypothesis in vitro by overexpressing the constitutively active (ca) form of ALK1 in cultured ECs using recombinant adenoviruses, and have reported their respective data, which were in disagreement. ${ }^{14,15}$ Lamouille et $a l^{14}$ found that ca-ALK1 inhibits the proliferation and migration of ECs, whereas Goumans et $a l^{15}$ observed the opposite phenomenon. Goumans et $a l^{16}$ recently reported that ALK5 kinase activity is required for optimal ALK1 activation by TGF- $\beta$ in ECs. Another report suggested that one of the TGF- $\beta$ type III receptors, Endoglin (ENG), is the key mediator for favoring TGF- $\beta$ /ALK1 over the TGF- $\beta$ /ALK5 pathway. ${ }^{17}$

TGF- $\beta$ is one of the most extensively studied growth factors. The TGF- $\beta$ subfamily members have been implicated in angiogenesis from the emergence of modern vascular biology, and, since this time, innumerable papers have described the diverse cellular functions of TGF- $\beta$ in ECs. However, the precise in vivo functions of TGF- $\beta$ in vascular development remain undefined. The existence, as well as the function, of the balance of the TGF- $\beta$ signal via ALK1 and ALK5 in vivo is also yet to be investigated.

Coexpression of ALK1 and ALK5 in the vascular ECs of embryos should be a precedent for the balance of TGF- $\beta$ signals through these two type I receptors. Using Alk1-lacZ knockin mice, we have previously shown that $A l k 1$ gene is predominantly transcribed/expressed in the arterial endothelium. Several reports have described expression patterns of Alk5 transcript and protein in developing mouse embryos using in situ hybridization and immunohistochemistry, but Alk5 expression in the vascular endothelium has been obscured. ${ }^{18-20}$

In order to investigate Alk5 expression in developing mouse embryos, and to compare it with that of $A l k 1$, we have generated a novel Alk5-lacZ knockin mouse line. The lacZ reporter expression was detected in multiple tissues, and was generally consistent with the Alk5-expression pattern previously reported. In blood vessels, the lacZ expression was strongly detected in smooth muscle cells (SMCs), but not in the ECs. These mutually exclusive in vivo expression patterns of two type I receptors suggest that TGF- $\beta$ is involved in vascular morphogenesis utilizing two distinct type I receptors: ALK1 in ECs and ALK5 in vascular SMCs.

\section{Materials and methods}

The $A l k 5^{\text {lac } Z}$ strain was generated at the University of Florida. C57BL/6J wild-type mice were purchased from Harlan (Indianapolis, IN, USA), and $F l k^{+/ l a c Z}$ mice were purchased from the Jackson Laboratory (Bar Harbor, ME, USA). All mice have been maintained under standard specific-pathogen-free (SPF) conditions, and the procedures performed on the mice were reviewed and approved by the University of Florida Institution of Animal Care and Use Committee (IACUC).

\section{Generation of the $A l k 5^{\text {lacz }}$ Mouse Line}

A mouse ES-129/SvJ BAC clone containing the Alk5 gene (Figure 1a) was identified by PCR-based screening and was purchased from Incyte Genomics (St Louis, MO, USA). A PstI-PstI $4.4 \mathrm{~kb}$ fragment containing a part of intron 2; a SIBN cassette; and a $4.8 \mathrm{~kb}$ PstI-PstI fragment containing a part of intron 3 , exons 4 , and a part of intron 4 were subcloned into pBluescript II vector (Figure 1b). The SIBN cassette contains SV40 splice donor and acceptor signals; internal ribosomal entry sequences; a bacterial $\beta$-galactosidase cDNA (lacZ) with a poly(A) signal; and a neomycin-resistant gene driven by a PGK promoter. Electroporation, G418 selection, and the Southern hybridization screening using the $3^{\prime}$ probe (Figure 1c and d) were performed as previously described. ${ }^{21} \mathrm{~A}$ total of 12 positive embryonic stem (ES) cell clones were obtained from 192 of the G418-resistant clones. ES cells from the positive clone \#44 were injected into the blastocysts of the C57BL/6 (B6) strain. The male chimeric offspring were mated with females on either B6 or 129S4/ 


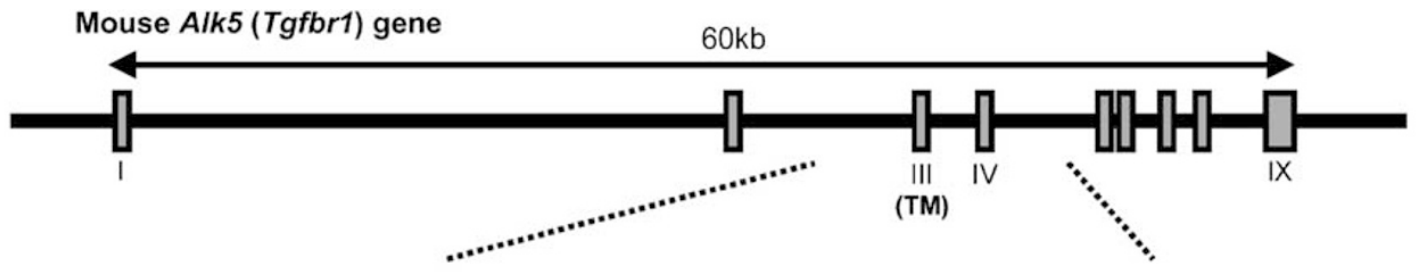

b

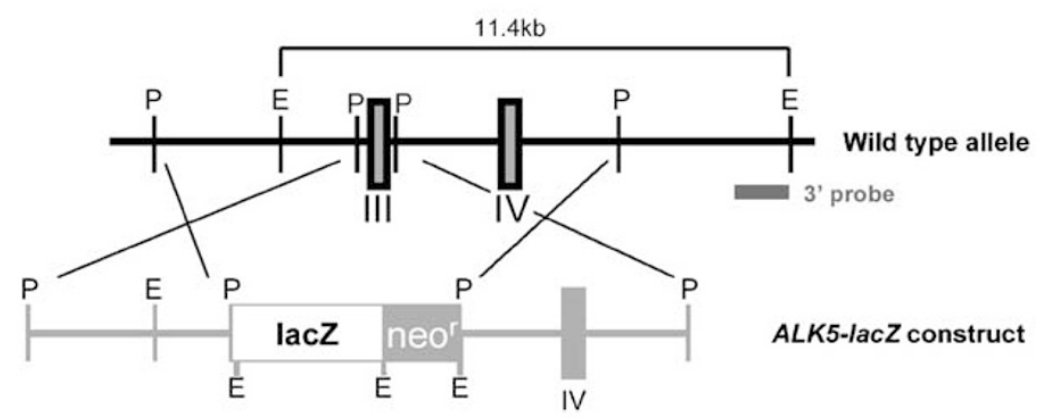

C
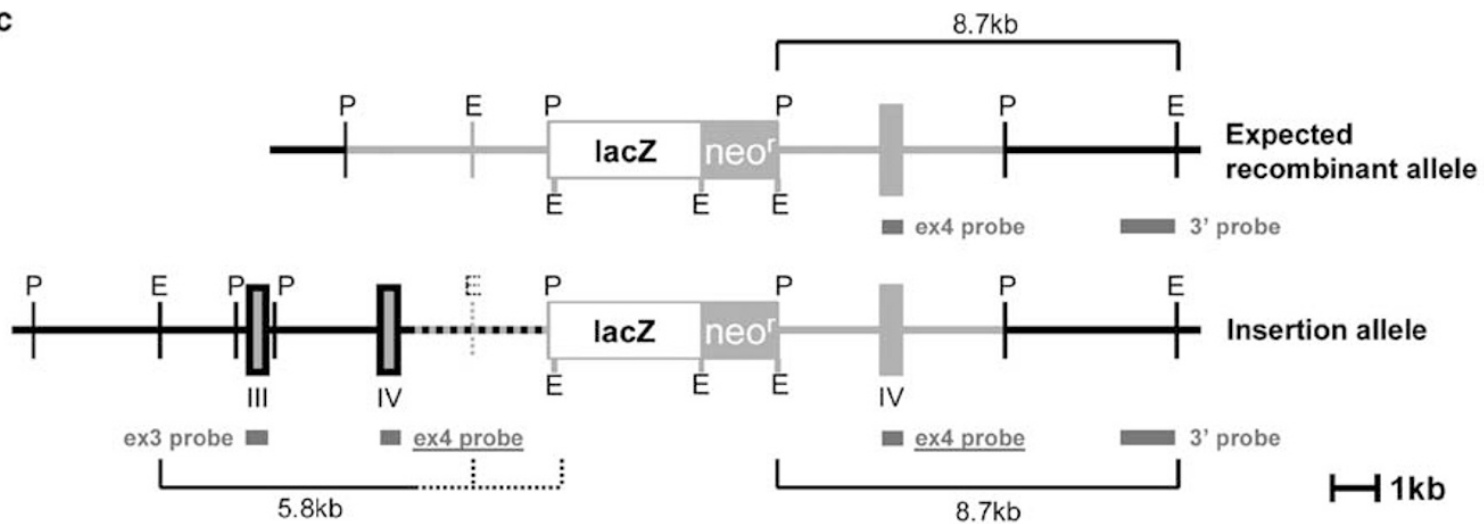

$\longmapsto 1 k b$

d

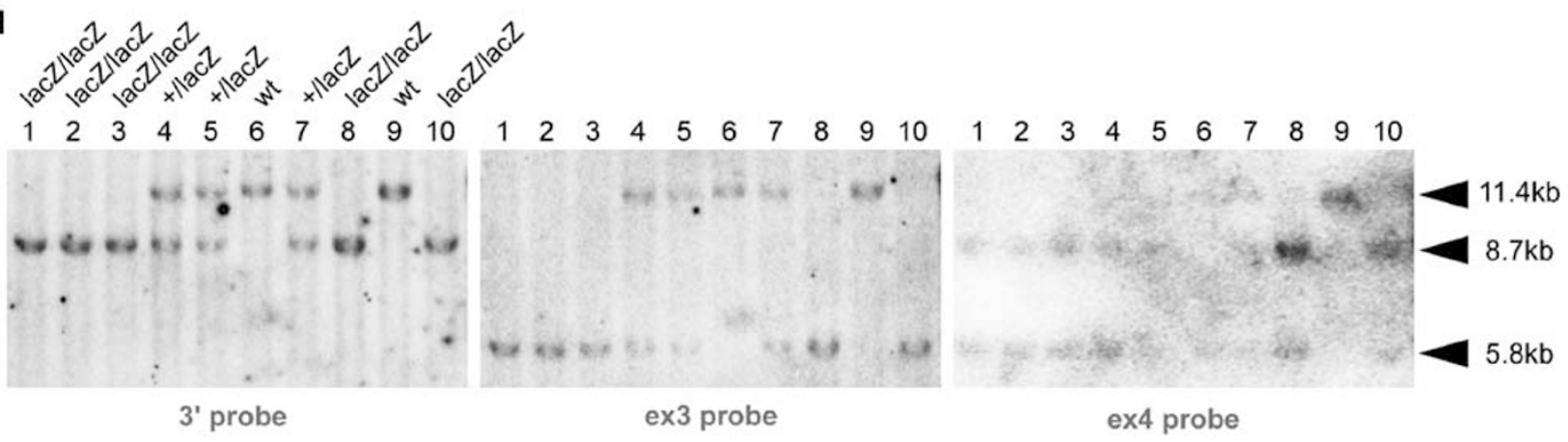

Figure 1 Analyses of the Alk5 lacZ allele. (a) A schematic diagram of mouse Alk5 gene structure. Boxes indicate exons. The translation start site resides in the first exon, and the transmembrane (TM) domain of Alk5 gene is encoded by the third exon (III). (b) A diagram of the Alk5 wild-type allele (in black) and the targeting construct that replaces the third exon with a lacZ reporter cassette (in gray). The lac $Z$ cassette consists of splice donor and acceptor sites; an internal ribosome entry site; a bacterial $\beta$-galactosidase gene (lacZ); and poly A signal sequences. The neor cassette consists of a PGK promoter; a neomycin-resistant gene; and the poly A signal sequences. (c) Diagrams of the expected recombinant allele from the targeting construct and of the insertion allele found in the $A l k 5^{\text {lacZ }}$ mouse line. Note that the exon 3 encoding transmembrane domain was still present, and that a part of the genomic region containing exon 4 (IV) was duplicated due to the insertion in the $A l k 5^{l a c z}$ allele. The length and organization between the $5^{\prime}$ exon 4 and the lacZ gene are yet to be determined (indicated by a dotted line). (d) Genomic Southern analyses of embryos from Alk5 $5^{+/ l a c Z}$ mice mating. Genotypes were as follows: Alk5 ${ }^{\text {lacZ/lacz }}$ (lanes 1, 2, 3, 8, and 10); Alk5 ${ }^{+/ l a c z}$ (lanes 4, 5, and 7); and wild type (lane 9). Genomic DNA from embryonic day 9.5 (E9.5) mice was digested with EcoRI, separated on agarose gel, and blotted on a nylon membrane. This membrane was then subjected to three-probe hybridization and deprobing cycles with the various probes indicated at the bottom. The $3^{\prime}$ probe was the one used for the initial screening. The probe location (dark gray bars) and the fragments detected by the probes are shown in (b) and (c).

SvJae (129) backgrounds. Heterozygous mice from the 129 strain were kept as a 129 inbred line. We found that there was no difference in expression patterns and mutant phenotypes between the 129 inbred and 129/B6 hybrid lines. We used the 129/B6 hybrid line for expression studies. 


\section{X-Gal Staining and Immunohistochemistry}

Mouse embryos and 3-month-old adult tissues were stained with a $\beta$-galactosidase substrate X-gal and were photographed before and/or after clearing as described. ${ }^{22}$ Paraffin-embedded whole-mount X-galstained samples were sectioned and counterstained with nuclear fast red (NFR) (Vector Laboratory, CA, USA). We also observed the sections without counterstaining to identify the weak X-gal staining, which may be masked by the NFR color. The following antibodies were used to identify specific proteins on the sections using the Vectastain immunohistochemical staining kits (Vector Laboratory, CA, USA): monoclonal anti-smooth muscle $\alpha$-actin (clone 1A4, Sigma-Aldrich, MO, USA) for detecting SMCs; polyclonal anti-CD68 (Santa Cruz Biotechnology, CA, USA) for macrophages; and antiOMP serum (a gift from Dr Margolis at the University of Maryland) for olfactory neurons. ${ }^{23,24}$

\section{Whole-Mount In Situ Hybridization}

To examine the SMC development in Alk5 lacZ/lacZ mouse embryos, embryos at 9.5 days post coitus (E9.5) were stained for SMC-specific marker SM22 $\alpha$ (transgelin; Tagln). An antisense probe against SM22 $\alpha$ mRNA was generated using degoxygenin UTP-labeling kit (Roche, IN, USA), and whole-mount in situ hybridization was performed as described. ${ }^{25}$

\section{Results}

\section{Generation of the Alk $5^{\text {IacZ }}$ Mouse Line}

In order to study the functions and expression patterns of the Alk5 gene, we targeted mouse Alk5 locus, and inserted a lac $Z$ cassette as a reporter. An Alk5-targeting construct was created in order to replace the PstI-PstI $0.9 \mathrm{~kb}$ fragment containing the third exon, which encodes a transmembrane domain, with a cassette containing the lacZ reporter gene. The linearized construct was electroporated into ES cells, and the G418-resistant ES cell clones were screened by genomic Southern blot using the $3^{\prime}$ probe (Figure 1). One of the targeted clones was randomly chosen to establish an Alk $5^{\text {lacZ }}$ mouse line.

Some of the embryos at 9.5 days post coitus (E9.5) from $A l k 5^{+/ l a c Z}$ matings appeared to be retarded, and the genomic Southern blot results using the $3^{\prime}$ probe consistently confirmed that these retarded embryos were homozygous for the $A l k 5^{l a c Z}$ allele (Figure 1d, left panel). When we genotyped these embryos with PCR primers within the PstI-PstI $0.9 \mathrm{~kb}$ fragment containing the exon 3; however, PCR amplifications occurred, indicating that the exon 3 might not be deleted in the Alk5 $5^{\text {lac }}$ allele. To investigate this possibility, we stripped the Southern blot membrane, and rehybridized it with the PstI-PstI $0.9 \mathrm{~kb}$ fragment (ex3 probe) as a probe. As shown in Figure 1d (middle panel), the exon 3 was indeed retained in the $A l k 5^{\text {lac } Z}$ allele. To further characterize the $A l k 5^{\text {lac } Z}$ allele, we performed one more Southern analysis using the same membrane with an exon 4 probe. The hybridization result showed that exon 4 was duplicated in the $A l k 5^{\text {lac } Z}$ allele (Figure 1d, right panel). These sequential Southern blot results revealed that the lacZ reporter cassette did not replace the exon 3 but was actually inserted into a $3^{\prime}$ region of exon 4 in the Alk5 locus, which consequently duplicated part of the genomic sequence in these mice (Figure 1c). Although the targeting fashion in this mouse line was not as initially planned, this insertion event kept this allele from losing regulatory elements in the $0.9 \mathrm{~kb}$ fragment, if any were present, and made this mouse line even more suitable for the Alk5 expression study.

\section{Alk5 ${ }^{\text {lacZ/acZ }}$ Mice Showed a Null Phenotype}

The homozygous Alk5 $5^{\text {lacZ/lacz }}$ embryos died around embryonic day 9.5 or 10.5 (E9.5 or E10.5), and showed severe growth retardation (Figure $2 \mathrm{a}$ and $\mathrm{b}$ ). The yolk sacs of homozygous mutant embryos at E9.5 had a wrinkled appearance and no visible blood-filled vessels. The embryo proper was also mildly or severely retarded (Figure 2c-e). At E10.5, the homozygous mutant yolk sac lacked mature vasculatures (Figure $2 \mathrm{f}$ and $\mathrm{g}$ ). These phenotypes are morphologically indistinguishable from the Alk5null embryos previously reported, ${ }^{26}$ suggesting that the $A l k 5^{\text {lac } Z}$ allele is null.

\section{X-Gal Staining Patterns of Alk5 $5^{+/ l a c Z}$ Embryos Represent Endogenous Alk5 ${ }^{\text {lac } Z}$ Expression Patterns}

By exploiting the reporter gene under the control of the endogenous Alk5 promoter, we analyzed Alk5 gene expression in $A l k 5^{+/ l a c Z}$ embryos at various developmental stages. As shown in Figure 3a-d, the whole-mount $\mathrm{X}$-gal staining revealed that lacZ is expressed in a variety of tissues and organs during embryonic development. The X-gal staining was particularly strong in connective tissues surrounding developing skeletons (Figure $3 \mathrm{~d}$ ).

In order to identify the cell types expressing lacZ, we have analyzed the histological sections of the Xgal-stained embryos and tissues. In the limbs, intense X-gal staining was found in the perichondrium and tendons (Figure $3 \mathrm{e}-\mathrm{g}$ ); and weaker staining was detected in the skeletal muscles and chondrocytes. The X-gal staining was also detected in the cardiac myocytes, especially in the trabecular muscles (Figure $3 \mathrm{~h}$ ). In the liver, a strong X-gal staining was detected in the mesenchymal layers surrounding biliary epithelium (data not shown). Weak or undetectable staining was found in neuronal tissues such as brain and spinal cord, except for a strong staining in cortices of the frontal lobe of the brain (data not shown). 

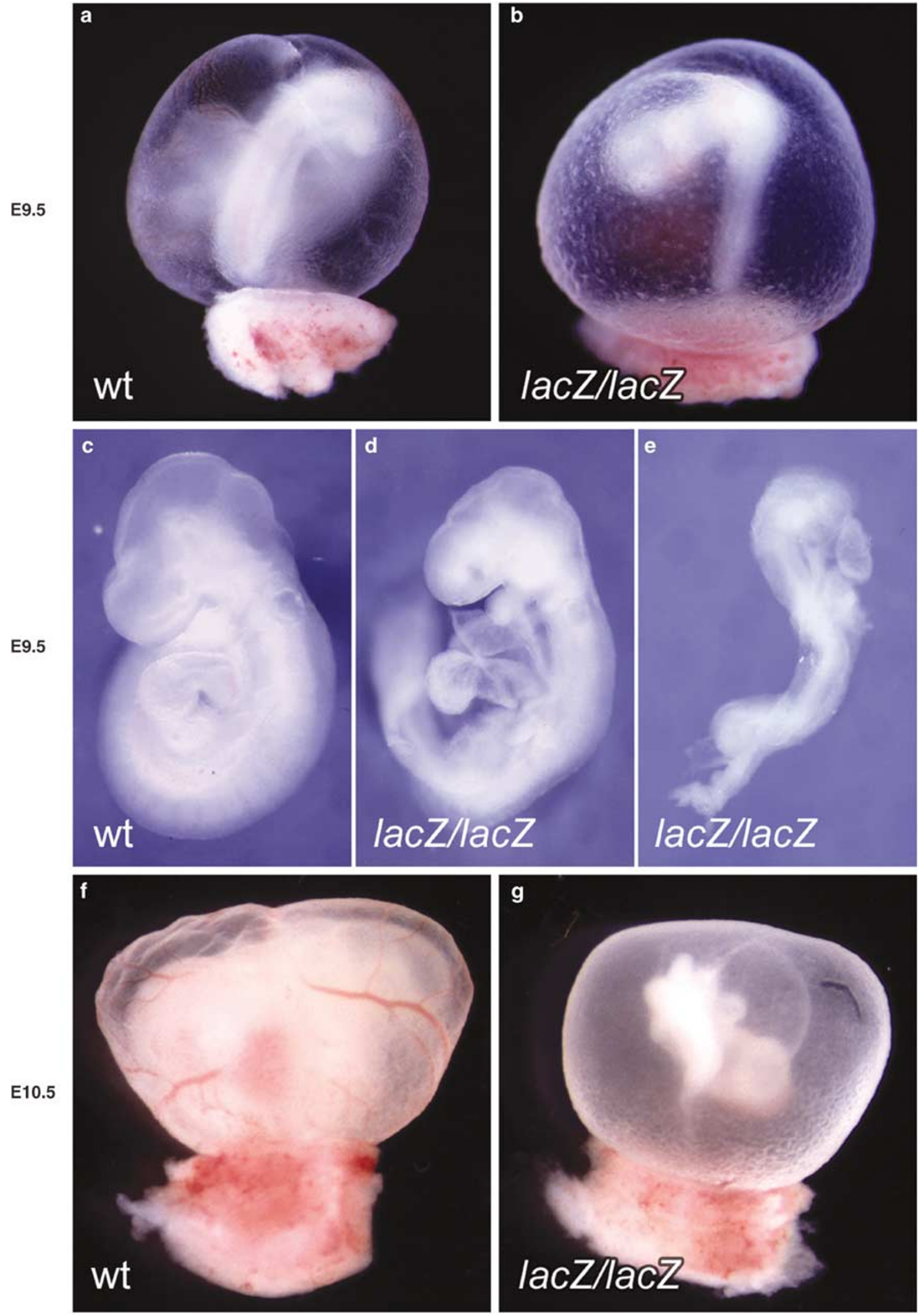

Figure $2 A l k 5^{l a c Z / l a c Z}$ mice exhibited phenotypes identical to those of the previously reported $A l k 5^{-/-}$mice. (a, b) In comparison with the yolk sac of the wild-type embryo (a), that of the $A l k 5^{l a c Z / l a c Z}$ embryo (b) shows a wrinkled appearance and has no apparent vasculature at E9.5. (c-e) E9.5 Alk5 $5^{\text {IacZ /lacZ }}$ embryos show either mild (d) or severe (e) retardation. (f, g) At E10.5, the mutant yolk sac lacks visible blood vessels and the embryo is severely retarded. 
a

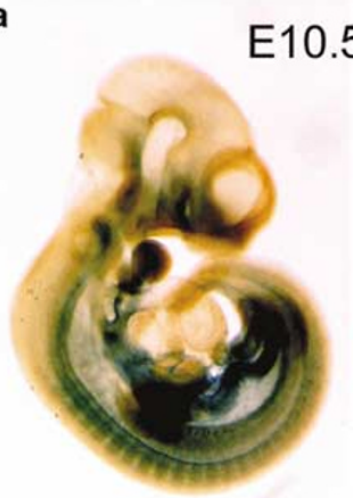

b

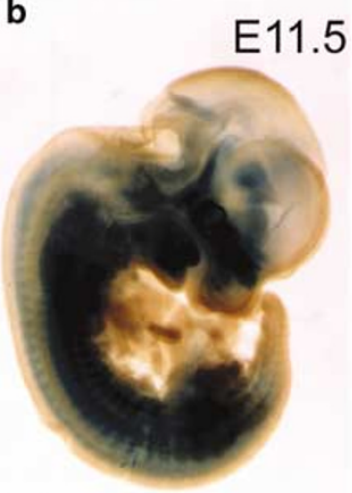

c

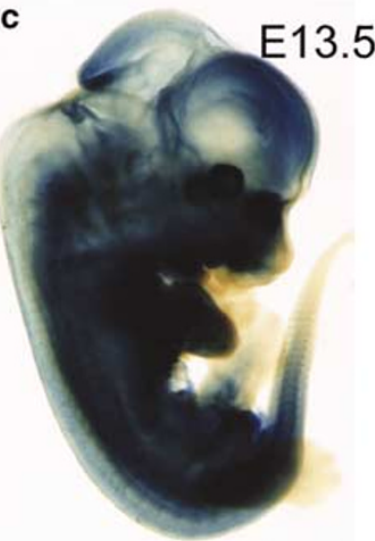

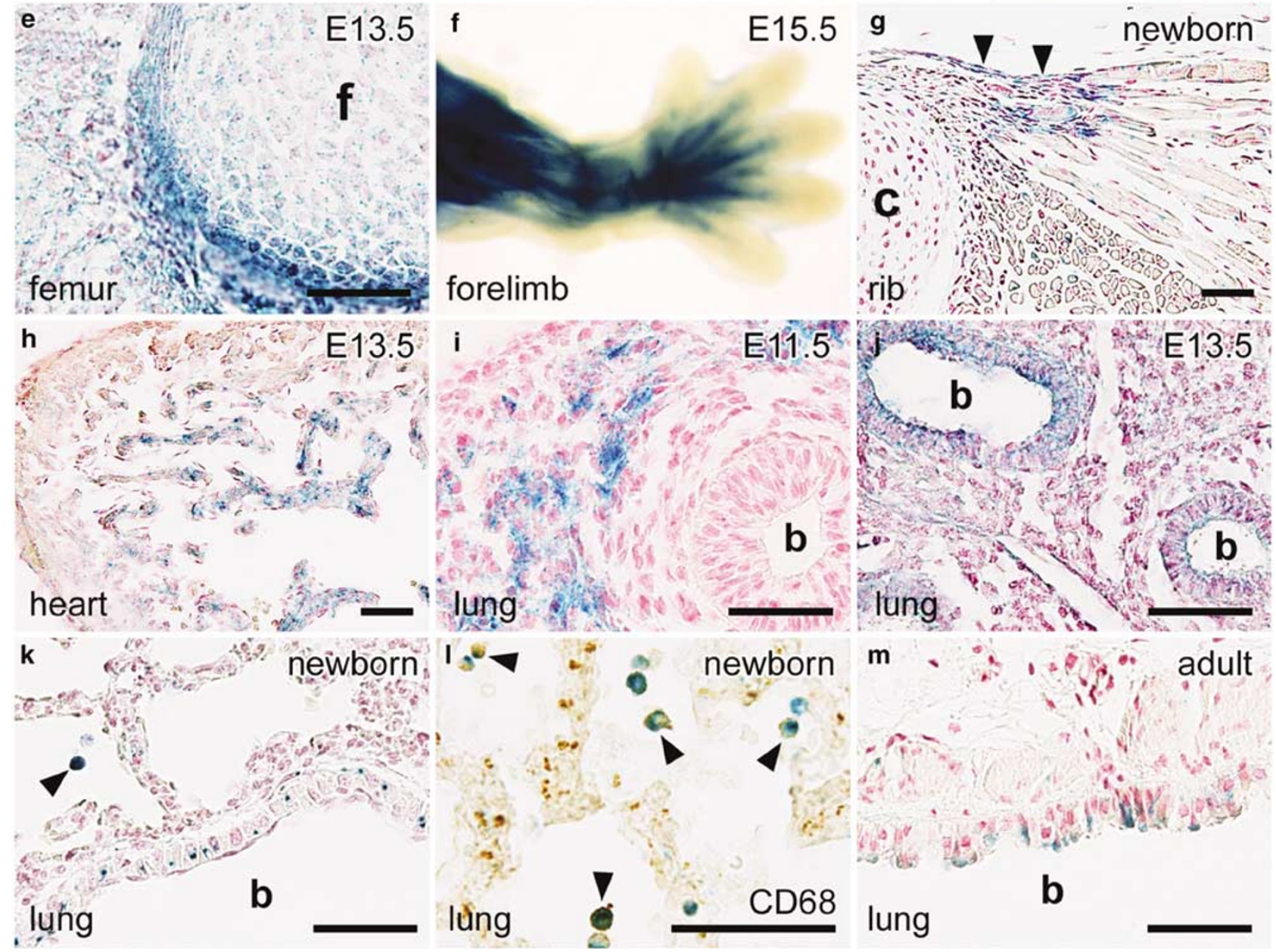

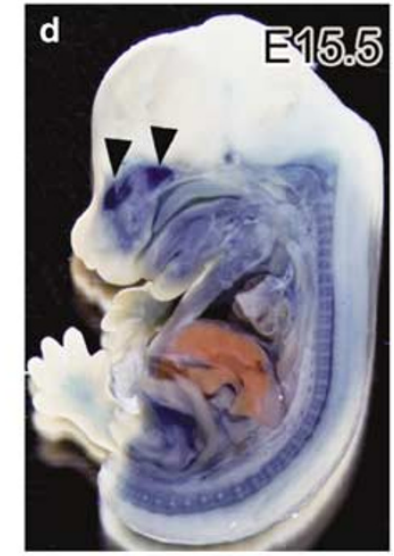

C

E15.5 g

Figure 3 Alk5 expression pattern revealed by X-gal staining of Alk5 $5^{+/ l a c Z}$ embryos. (a-c) Whole-mount X-gal staining of Alk5 $5^{+/ l a c Z}$ embryos at E10.5 (a), E11.5 (b), and E13.5 (c). X-gal-stained embryos were cleared with organic solvents for whole-body observation. (d) A mid-body sagittal section of an E15.5 embryo stained with X-gal. The most intense staining was observed in the olfactory area (arrowhead). (e) Perichondral staining of the developing femur (f) at E13.5. (f) Whole-mount view of cleared forelimb displays X-gal staining in developing bones, tendons, and muscles of E15.5 embryos. (g) X-gal staining in a pre-tendon tissue (arrowheads) on the rib cartridge (c). (h) Trabecular muscles in the heart express $\beta$-gal at E13.5. (i-m) X-gal staining patterns in the lungs throughout development. At E11.5, X-gal staining was initially observed in mesenchymal tissue, but not in the bronchial epithelium (i). As development proceeds, the epithelial cells lining the bronchi (b) express $\beta$-gal (j). Epithelial expression persists at the adult stage while mesenchymal expression diminishes (m). At the newborn stage, infiltrated macrophage lineage cells show $\beta$-gal expression (arrowheads in $\mathbf{k}$ and $\mathbf{l}$ ). Double staining with a tissue macrophage-specific antigen CD68 confirms the cell type (l). Scale bars in (e), (g), and (h-m) are equal to $50 \mu \mathrm{m}$.

In the E11.5 lungs, the X-gal staining was detected in the mesenchymal tissue of future parenchyma, but not in the epithelial lining of developing airways
(Figure 3i). Zhao et al reported that Alk5 is expressed in both mesenchymal tissue and the bronchial epithelium, but is more intense in the 
bronchial epithelium of the developing rat lungs at gestational day 14 (Gd14).$^{20}$ Comparable expression patterns-with higher expression in the airway epithelium than in the mesenchyme-were observed in the mouse lungs at E13.5, which corresponds to rat Gd15 (Figure 3j). The bronchial epithelial staining was detected throughout the adult stage (Figure $3 \mathrm{k}$ and $\mathrm{m}$ ). In addition, intense staining was found in CD68-positive macrophage cells in the alveolar cavities at the newborn stage (Figure 3k and l).

These X-gal staining patterns in various organs of $A l k 5^{+/ l a c Z}$ embryos were consistent with the previously reported Alk5 expression patterns observed by in situ hybridization and immunohistochemical methods, ${ }^{18-20}$ suggesting that the X-gal staining patterns of the Alk5 $5^{+/ l a c Z}$ mice represent the in vivo Alk5 expression patterns, and thus we refer to the lacZ expression in $A l k 5^{+/ l a c Z}$ mice as 'Alk5 expression' hereafter.

\section{Alk5 Expression in the Olfactory Epithelium (OE)}

The strongest Alk5 expression in E15.5 embryos was observed in the olfactory area (Figure 3d). Alk5 expression in the OE of E14.5 mouse embryos was reported, ${ }^{10,19}$ but no detailed expression patterns of Alk5 in the developing $\mathrm{OE}$ have been shown. We detected Alk5 expression in the OE as early as E11.5 (Figure 4a). The neuronal lineage cells in the OE become fully established, and the active neurogenesis begins at E14.5. ${ }^{27}$ Around this stage, Alk5 expression begins to be restricted in the basal layer of the $\mathrm{OE}$ (Figure 4b and c). Several cell types reside in the OE proper: olfactory receptor neurons (ORNs) and their progenitors; sustentacular cells (supporting cells found in a single apical layer); as well as horizontal basal cells (cells that lie immediately atop the basal lamina) (Figure 4f). The expression of Alk5 was detected in ORNs and basal cells, but not in sustentacular cells at E13.5 and E15.5. Double staining of X-gal and anti-olfactory marker protein (OMP) antibodies ${ }^{23}$ revealed that ORNs and their progenitor cells express Alk5 (Figure $4 \mathrm{~d}$ and e). The Alk5 staining was detected in a subset of the olfactory nerve axons as well (Figure $4 \mathrm{~d}$ and g). The wholemount X-gal staining of the E18.5 olfactory cavity showed that Alk5 is expressed in the OE, but not in the respiratory epithelium (Figure 4h). Since Alk5 expression in neuronal tissues was generally undetectable (Figure 3d), the ORN staining in the OE is unique in its high Alk5 expression. We speculate that
ALK5 may mediate a TGF- $\beta$ family signal important for the development of ORN in the OE.

\section{Alk5 is Expressed in the Vascular Smooth Muscle Cells, but not in the ECs of the Embryonic Aorta}

Multiple mechanistic roles of ALK1 and ALK5 as TGF- $\beta$ type I receptors in vascular ECs have been proposed. The premise of such proposals is that both ALK1 and ALK5 are expressed in vascular ECs. We have shown that ALK1 is predominantly expressed in arterial ECs during the embryonic and neonatal stages. ${ }^{22}$ However, comprehensive ALK5 expression studies on blood vessels have not been reported. Using the Alk5 $5^{+/ l a c Z}$ embryos, we investigated Alk5 expression in developing blood vessels and compared it with Alk1 expression in the Alk1+llacZ embryos (Figure 5).

In low-power magnification views, both Alk1 and Alk5 were expressed in the dorsal aortas of the $A l k 1^{+/ l a c Z}$ and $A l k 5^{+/ l a c Z}$ embryos (Figure $5 \mathrm{a}$ and b). In high-power views, however, these two type-I receptors displayed mutually exclusive expression patterns: Alk1 was detected in a single layer of the ECs, whereas Alk5 was in multiple layers of the cells surrounding the ECs, but not in the ECs themselves (Figure $5 \mathrm{c}$ and d). Immunostaining with anti-smooth muscle $\alpha$ actin antibodies showed that the X-galpositive cells in the $A l k 5^{+/ l a c Z}$ embryo were SMCs (Figure 5e and f). The weak Alk5 expression was also detected in mesenchymal tissue surrounding the aorta, but there was no detectable Alk5 expression in the ECs. In fact, regardless of arterial, venous, or capillary, no Alk5 positive ECs was found in any of the over 100 histological sections, which produced from the embryos proper at various developmental stages.

\section{Alk5 Expression is Undetectable in any Endothelial Lineage Cells}

We further analyzed Alk5 expression in various endothelia in $A l k 5^{+/ l a c Z}$ mice at several postnatal stages (Figure 6). In order to detect weak X-gal staining, the histological sections were also examined without the counterstaining. The intense Alk5 expression was observed in the vascular SMCs, but not in the ECs, of both newborn and adult aortas (Figure 6a and b). The ECs in both the arterioles and the venules of the newborn tongues were also negative for Alk5 expression (Figure 6c and d). The ECs on semilunar valves, which transdifferenti-

Figure 4 Alk5 expression in the olfactory epithelium (oe).(a-c) At E11.5, the entire oe has staining (a), which is gradually restricted to the base of the epithelium along with the development progress by E15.5 (b, c). nc: nasal cavity. (d, e, and g) Double staining of the olfactory tissue with X-gal and the antibody against olfactory marker protein (OMP) at E15.5. High-power magnification shows that basal cells and developing olfactory cells (shown in e), as well as certain olfactory axons (shown in g), are stained with X-gal. (f) Schematic drawing of the olfactory tissue shown in (e). Sustentacular cells (SCs) at the luminal surface were X-gal negative, whereas basal cells (BCs) expressed lacZ. The brown circles indicate olfactory receptor neurons (ORNs), some of which were X-gal positive. (h) Whole-mount X-gal staining of the nasal cavity at E18.5. Note that the olfactory, but not the respiratory, region expresses Alk5. Scale bars in a-f are equal to $50 \mu \mathrm{m}$. 


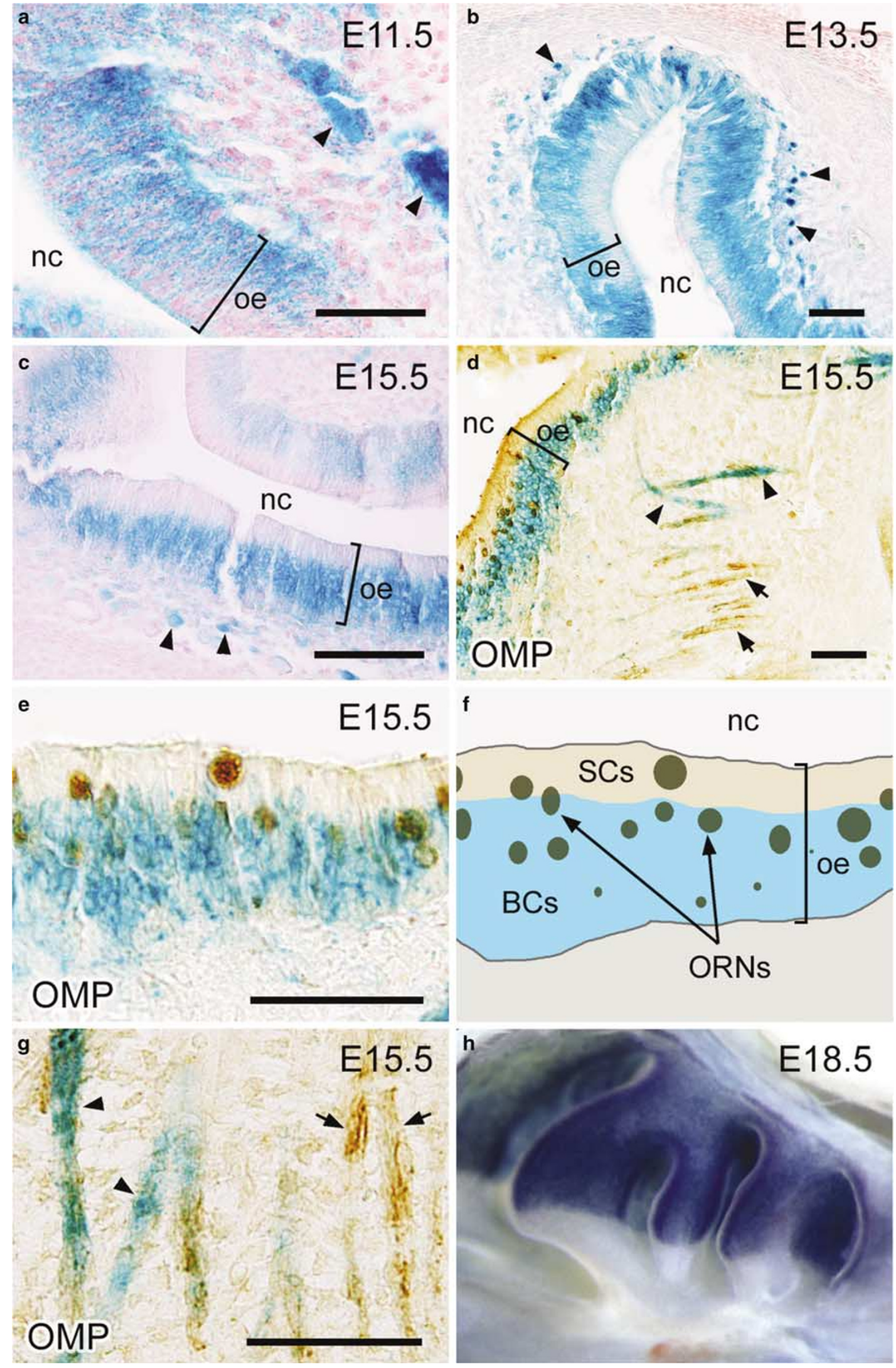


ate to produce valvular mesenchymal cells, ${ }^{28}$ were negative for Alk5 expression, whereas the valvular mesenchymal cells expressed Alk5 (Figure 6e and f). Similarly, Alk5 was expressed in ventricular muscles, but not in the endocardium (Figure 6e). Overall, these expression studies show that Alk5 is predominantly expressed in muscle and mesenchymal cells, but not in the adjacent endothelial lineage cells.

\section{Vascular Morphogenesis in Alk5 ${ }^{\text {lacZ/lacZ }}$ Mice}

As shown in Figure 2, Alk5 $5^{\text {lacZllacZ }}$ embryos die around E9.5. Morphologically, the Alk5 $5^{\text {lacZllacZ }}$ phenotype is indistinguishable from the Alk5-knockout $\left(A l k 5^{-1-}\right)$ embryos previously published by an independent group. ${ }^{26}$ Since the vascular phenotype of the $A l k 5^{-\prime-}$ embryo proper was not described in the $A l k 5^{-/-}$report, we have investigated whether Alk5 deficiency affects embryonic vascular development. In order to visualize the ECs, we crossed Alk5 $5^{+/ l a c Z}$ mice with Flk1 $1^{+/ l a c Z}$ mice in which the lacZ gene is inserted into vascular endothelial growth factor receptor 2 (Kdr, Vegf-r2, Flk1) locus. ${ }^{29}$ Additional heterozygous Flk1 mutation in the Alk5 lacZllacZ mice did not appear to alter their phenotypes, and the same approach was successfully used for the characterization of $A l k 1^{-1-}$ embryos in our previous study. ${ }^{12}$ Therefore, this approach enabled us to compare the vascular phenotype of Alk5 $5^{\text {laczllacz }}$ directly with that of the

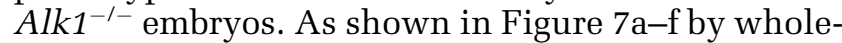
embryo X-gal staining, the vascular networks in E9.5 Alk5 $5^{\text {IacZ/lacZ }}$ embryos appeared unaffected in spite of severe growth retardation. The histological sections of these embryos revealed that the shapes and sizes of the blood vessels in Alk5 mutant embryos were comparable to those of the wild-type embryos (Figure $7 \mathrm{~g}$ and $\mathrm{h}$ ). Since Alk5 was expressed in vascular SMCs, we examined SMC development in Alk5 mutant mice. An antisense SM22 $\alpha$ probe detected SM22 $\alpha$ transcripts in the heart tube, but not in the dorsal aorta of Alk5 $5^{\text {lacZllac } Z}$ embryos, indicating defects in the vascular smooth muscle development of these mutant embryos (Figure 7i and j).

\section{Discussion}

In this study, we demonstrated Alk5 expression patterns during development and postnatal life using a novel knockin mouse line that carries lacZ reporter in the Alk5 gene locus $\left(A l k 5^{\text {lac } Z}\right)$. We showed that the expression patterns of lac $Z$ recapitulated those of previously reported Alk5, and that Alk5 was expressed in a nonubiquitous and dynamic manner during development. In the blood vessels, Alk5 was predominantly expressed in the smooth muscle layer, but was undetectable in the endothelial layer. We also revealed that Alk5- deficient embryos had impaired vascular smooth muscle layer development. Unlike Alk1-deficient embryos, however, Alk5-deficient embryos formed relatively normal capillary networks. Based on these data, we propose that TGF- $\beta$ is involved in vascular morphogenesis utilizing two distinct type I receptors: ALK1 in ECs and ALK5 in vascular SMCs (Figure 8).

Throughout developmental stages, a high expression of Alk5 was detected in fiber-rich connective tissues, such as the periosteum, perichondrium, tendons, and ligaments, as well as in the mesenchymal layers supporting the epithelia. These observations are consistent with one of the key functions of TGF- $\beta$ - the production of extracellular matrix (ECM) proteins-and with the previous reports showing the Alk5-expression patterns using in situ hybridization with Alk5 antisense probes. ${ }^{18-20}$ In addition, we found dynamic changes in Alk5 expression patterns during development of specific epithelial layers. In the lung, Alk5 expression was detected in the mesenchymal tissue of future parenchyma, but not in the epithelial lining of the developing airways of E11.5 lungs. As development proceeded, the airway epithelium of E13.5 lungs showed a high level of Alk5 expression.

Another dynamic expression pattern was observed in the OE. At E11.5, uniform Alk5 expression was found in olfactory epithelial cells. At around E14.5, when the active neurogenesis occurs in the OE, the Alk5 expression became restricted in the basal layer of the $\mathrm{OE}$ and in the olfactory neurons, but not in the sustentacular cells located in the apical layer of the OE. Growth differentiation factor 11 (GDF11) has been implicated in the determination of the size of the OE. ${ }^{10} \mathrm{~A}$ recent report showed that GDF8, the closest TGF- $\beta$ family member of GDF11, can transduce its signaling via ALK5 and ACVR2B. ${ }^{9}$ The dynamic expression pattern of Alk5 in OE development may suggest that ALK5 is the type I receptor for the GDF11 signaling in OE development.

Angiogenesis refers to the processes by which new vessels form by sprouting or splitting from preexisting vessels. ${ }^{30}$ Angiogenesis can be separated into two distinct phases: activation and resolution. ${ }^{31}$ In the activation phase, ECs degrade their vascular basement membranes, migrate into extracellular spaces, proliferate, and form vascular lumens. During the resolution phase, ECs cease the migration, stop proliferation, and instead reconstitute their ECM proteins. The maturation and remodeling of the vessels also occur in this phase, as the mesenchymal cells are recruited for endothelialtube encasement. Such cells include pericytes for small capillaries and vascular SMCs for larger vessels.

Several growth factors are reported to play important roles in the resolution phase of angiogenesis, which include angiopoietin-1 (ANG1), ${ }^{32}$ platelet-derived growth factor B (PDGFB), ${ }^{33,34}$ and 
ALK1
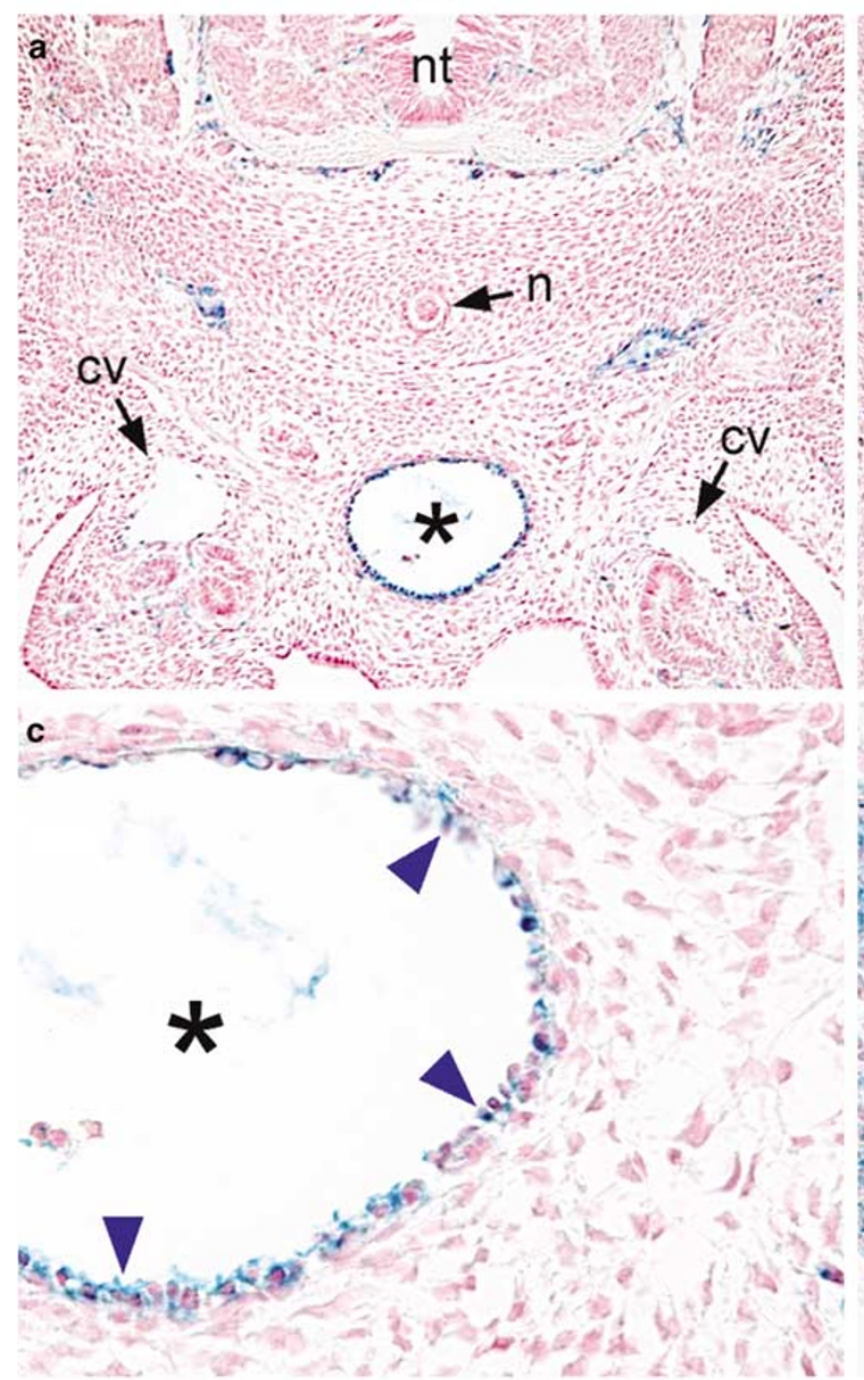
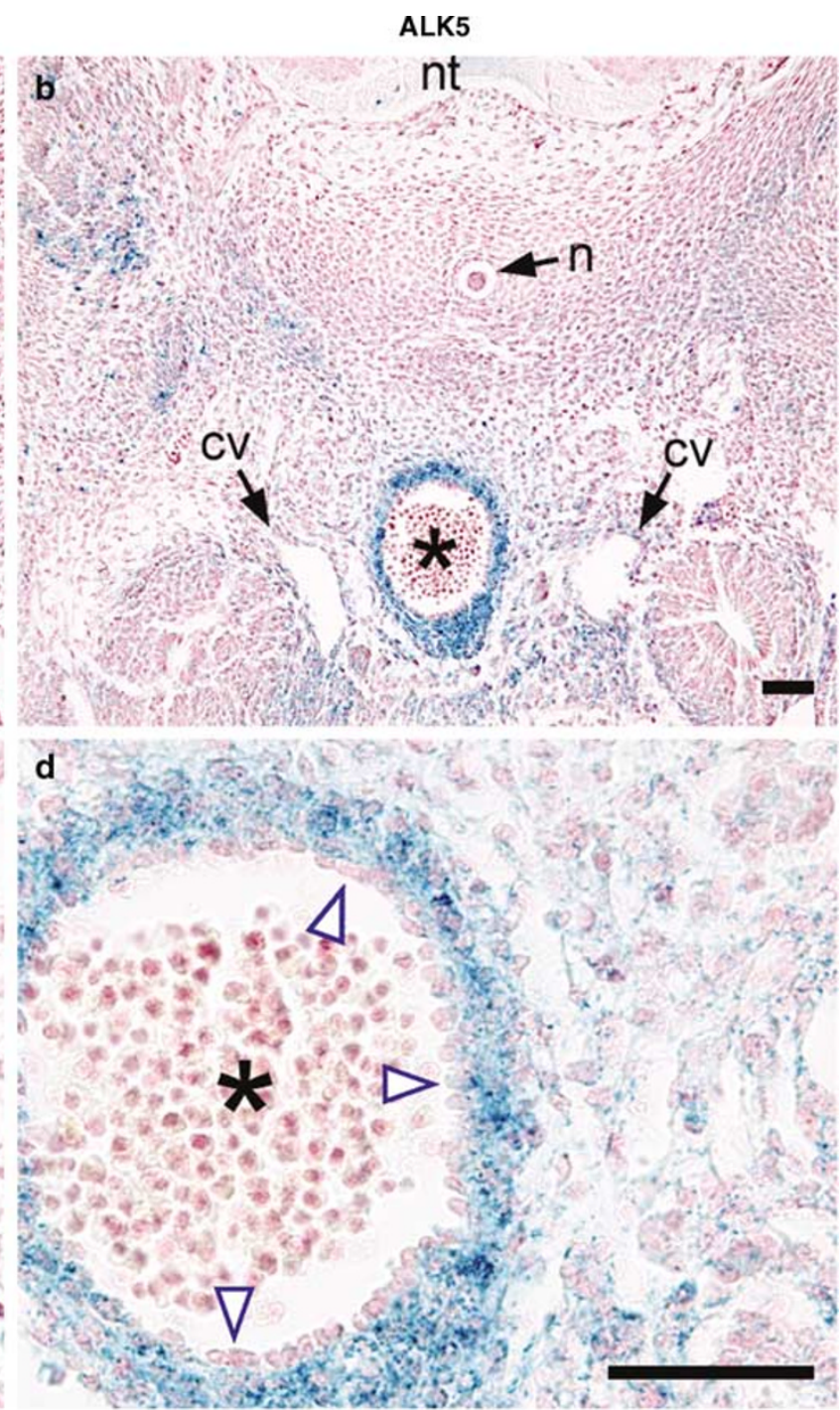

f

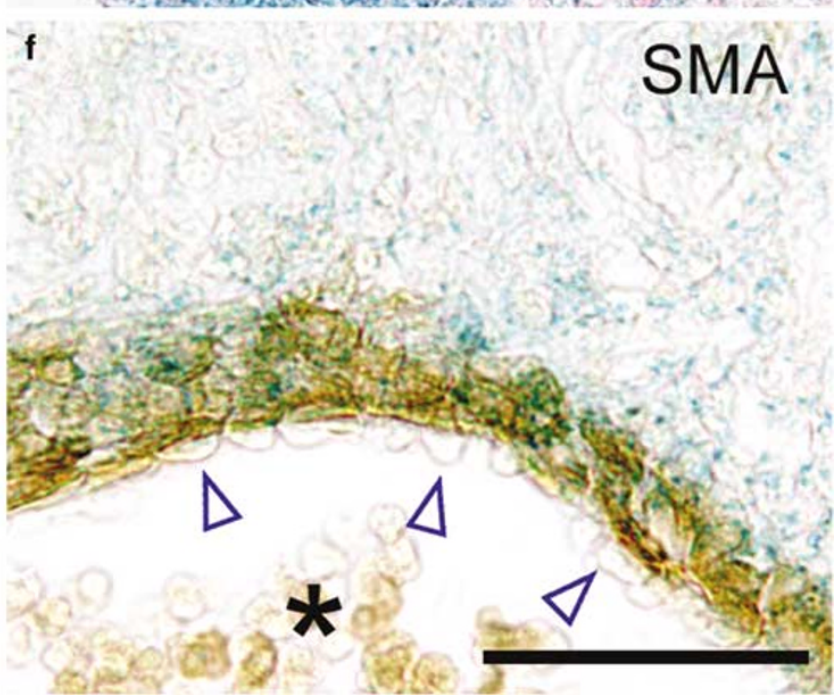

Figure 5 Vascular expression patterns of $A l k 1$ and Alk5 in E11.5 embryos. (a, b) Low-power magnification reveals that both Alk1 (a) and Alk5 (b) are expressed in dorsal aortas (asterisk). (c, d) Magnified view of the dorsal aortas in (a) and (b). Alk1 is expressed in vascular ECs as a single intimal layer of the dorsal aorta (c), whereas Alk5 is expressed in the multiple layers of the smooth muscle cells surrounding the ECs, but not in the ECs (d). (e, f) Double staining with X-gal and the antibody against smooth muscle $\alpha$ actin (SMA) further confirms that Alk1 is expressed in ECs (e) and that Alk5 is expressed in smooth muscle cells (f). Panels of (a and b), (c and $\mathbf{d})$, as well as (e and $\mathbf{f})$ in individual pairs have identical magnifications. Scale bars in (b), (d), and (f) are equal to $50 \mu \mathrm{m}$. 

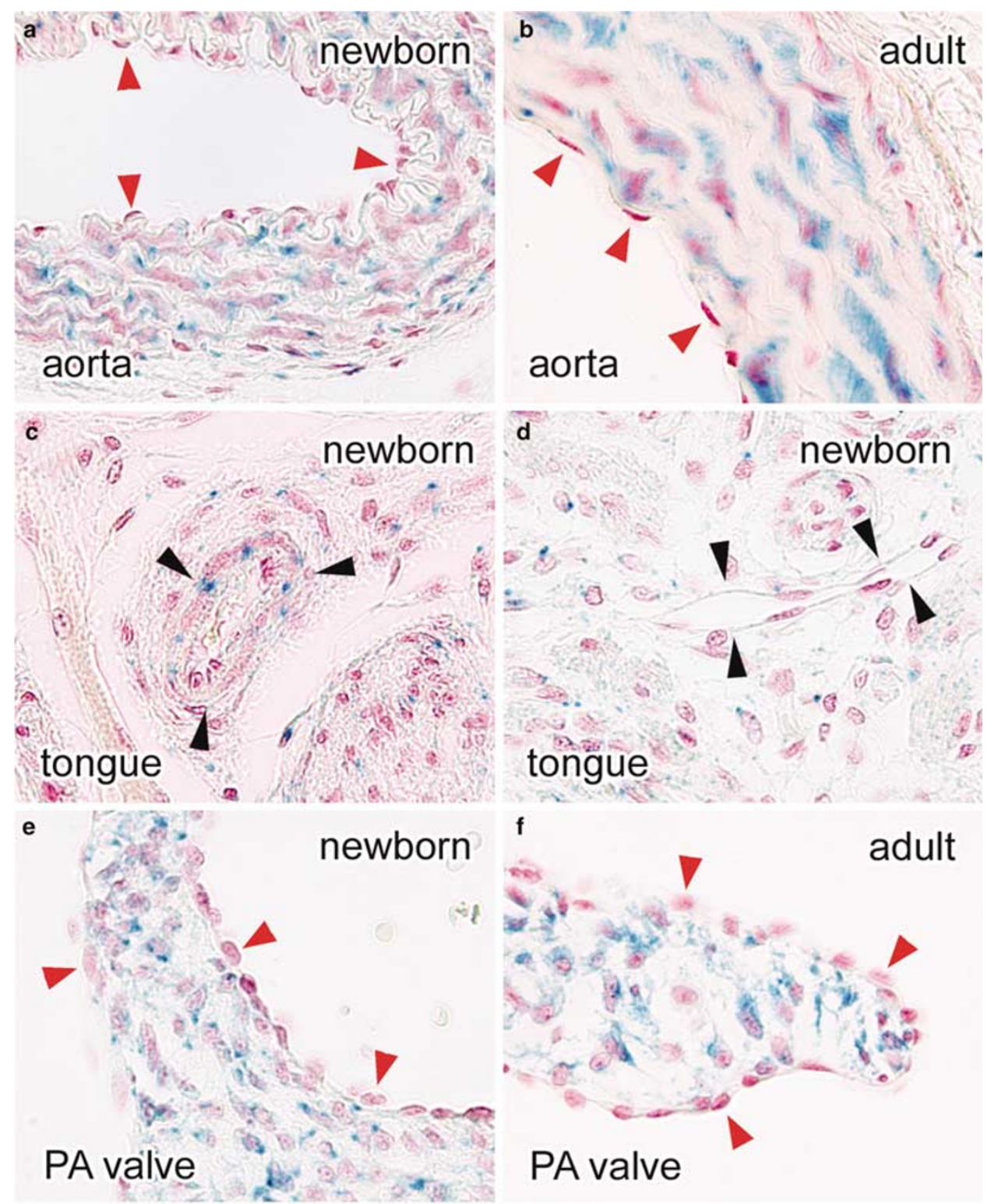

g

newborn

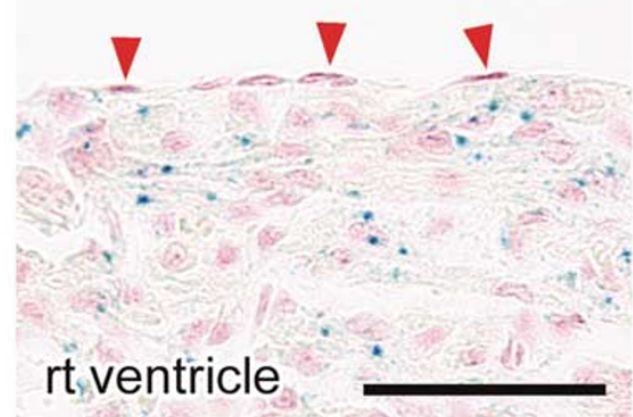

Figure 6 Alk5 expression is undetectable in any endothelial lineage cells in various developmental and postnatal stages. (a-d) Endothelial cells (red arrowheads) in newborn and adult aortas, as well as small arteries and veins in newborn tongues (black arrowheads) show no detectable Alk5 expression. Note intense Alk5 expression in the vascular SMCs (a-c). (e, g) Endothelial cells on the pulmonary artery valve of newborn (e) and adult (f) mice, as well as on the endocardium in the right ventricle of a newborn mouse (g) are negative for X-gal staining (red arrowheads). All panels are in the same magnification. Scale bar in (g) is equal to $50 \mu \mathrm{m}$. 

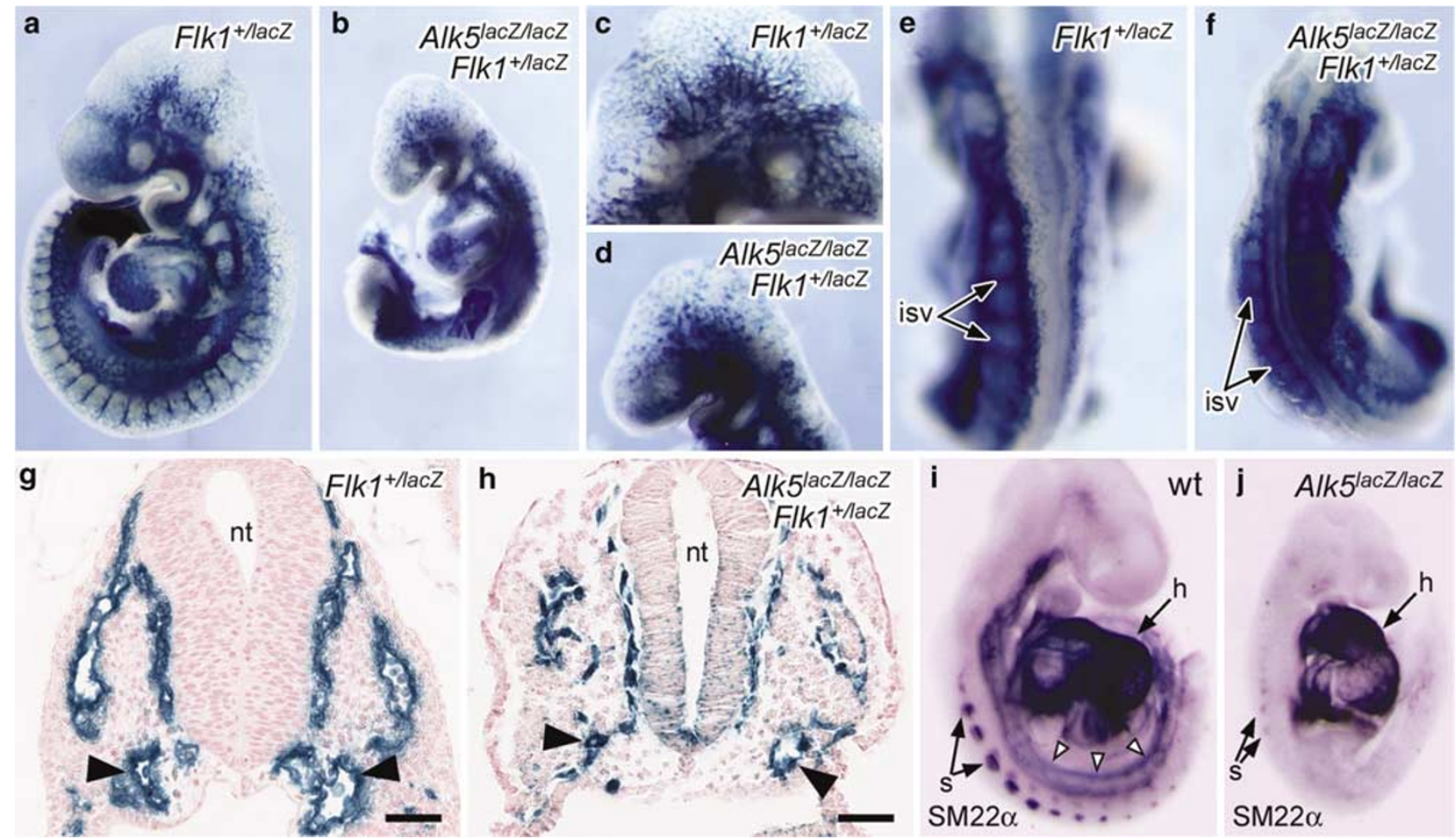

Figure 7 Vascular morphogenesis in the E9.5 Alk5 $5^{l a c Z / l a c Z}$ embryo proper. The lacZ gene inserted into Flk1 locus was utilized to visualize endothelial cells in embryos. (a-f) Although the Alk $5^{\text {lacz/lac } Z}$ embryo (b, $\mathbf{d}$ and $\mathbf{f}$ ) is retarded compared with $A l k 5^{+/+}(\mathbf{a}, \mathbf{c}$, and e), the network structure of blood vessels in the body seems unaffected. Note that the intersomitic vessels are properly formed (f). (g and h) Histological analysis shows that the lumen size and shape of the dorsal aortas (arrowheads) of the Alk $5^{\text {lac } Z / l a c z}$ embryos (h) are comparable to those found in wild-type mice (g). (i and $\mathbf{j})$ In situ hybridization with an anti-SM22 $\alpha$ antisense probe revealed a defect in smooth muscle cell development in the aortas of $A l k 5^{\text {lacZ/lacZ }}$ embryos. Scale bars in (g) and (h) are equal to $50 \mu \mathrm{m}$.

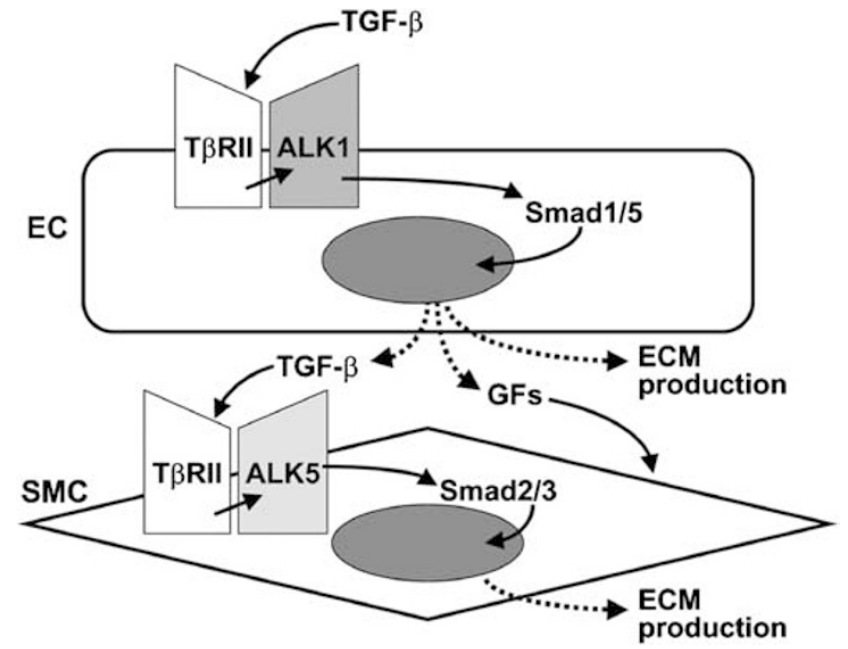

Figure 8 A model of TGF- $\beta$ signalings for the vascular maturation and remodeling. TGF- $\beta$ signal is mediated by ALK1 in ECs and ALK5 in vascular SMCs for the growth regulating as well as extracellular matrix (ECM) protein synthesis for the maturation of the vessel wall. TGF- $\beta$ signal in ECs produces growth factors (GFs) including TGF- $\beta$ itself, which regulate growth, differentiation, and ECM production of the neighboring SMCs.

TGF- $\beta .^{35}$ In fact, TGF- $\beta$ signaling has been considered as a key component in the resolution phase of angiogenesis and maturation of blood vessels. Based on coculture studies of ECs and SMCs, it was postulated that interactions of perivascular cells and ECs can activate the latent form of TGF- $\beta$, which in turn induces differentiation of mesenchymal cells into perivascular cells, inhibits EC proliferation, and stimulates ECM deposition. ${ }^{36}$ In terms of mitogenic activities, TGF- $\beta$ has been shown to either promote or inhibit the proliferation of ECs, depending on the concentration of TGF- $\beta$, cell types, culture conditions, or presence of other regulators. ${ }^{31}$ The previously proposed balance models of the TGF- $\beta$ signals in ECs via two type I receptors might explain for the mechanism underlying these biphasic effects of TGF- $\beta$ : the concentrations of TGF- $\beta$ could selectively activate ALK1 or ALK5 signaling pathway which may be a determinant of the proliferation status of ECs. ${ }^{12,15}$ More complex interactions between these two pathways have also been reported. ${ }^{16,17}$ Paradoxically, our expression studies using the lac $Z$ knockin mice indicate the mutually exclusive expression of Alk1 and Alk5 in blood vessels: ALK1 in ECs and ALK5 in vascular SMCs (Figure 5).

These expression data raise the question of whether the proposed in vitro roles of the two TGF- $\beta$ signaling pathways via ALK1 and ALK5 are valid for in vivo vascular development. One explanation for this discrepancy is that our knockin 
system might not be sensitive enough to detect a low level of Alk5 expression in the ECs. Since we have used the same lac $Z$ expression cassette in both the Alk1 and Alk5 knockin lines, however, it is indisputable that $A l k 1$ is predominantly expressed over Alk5 in ECs, and vice versa in the vascular SMCs. An alternative explanation is that similar levels of Alk1 and Alk5 expression in cultured ECs may not be representing a normal in vivo situation, but rather they occur in the cells under a non-physiological condition. In other words, the balance mechanism in ECs may exist only in very limited circumstances in vivo.

With these in view, we propose a model for the role of the TGF- $\beta$ signal in vascular development. The TGF- $\beta$ signal is mediated by ALK1 in ECs and by ALK5 in vascular SMCs, and the TGF- $\beta$ signal in ECs via ALK1 modulates the proliferation and migration of vascular SMCs and/or the matrix protein synthesis by vascular SMCs (Figure 8). The modulation mechanism may include autoregulation of TGF- $\beta$ secretion from ECs, which can be relayed to the adjacent vascular SMCs. This model further implicates the role of TGF- $\beta$ in the maturation, stabilization, and remodeling of blood vessels. It has previously been shown that Alk1 is predominantly expressed in arterial ECs, and is upregulated by shear stress. Such a specific regulation of the receptor expression is one possible reason why two different receptors exist for the TGF- $\beta$ signaling in blood vessels.

TGF- $\beta$ has been implicated in a diverse range of pathological conditions, including inflammation, wound healing, regeneration, aging, and cancer to list a few. The Alk5 ${ }^{\text {lac } Z}$ mice together with previously reported Alk1 ${ }^{1 a c Z}$ mice will be valuable animal models in identifying the in vivo cellular targets of TGF- $\beta$ family signals during various pathogeneses.

\section{Acknowledgements}

We thank Dr Margolis at the University of Maryland for anti-OMP serum, and Marya Park for editorial assistance. This work was supported by NIH (HL64024) to SPO.

\section{References}

1 Massague J. TGF-beta signal transduction. Annu Rev Biochem 1998;67:753-791.

2 Massague J. How cells read TGF-beta signals. Nat Rev Mol Cell Biol 2000;1:169-178.

3 Wrana JL, Attisano L. The Smad pathway. Cytokine Growth Factor Rev 2000;11:5-13.

4 Derynck R, Zhang YE. Smad-dependent and Smadindependent pathways in TGF-beta family signalling. Nature 2003;425:577-584.

5 Piek E, Heldin CH, ten Dijke P. Specificity, diversity, and regulation in TGF-beta superfamily signaling. FASEB J 1999;13:2105-2124.
6 Lee SJ, McPherron AC. Regulation of myostatin activity and muscle growth. Proc Natl Acad Sci USA 2001;98:9306-9311.

7 Yeo C, Whitman M. Nodal signals to Smads through Cripto-dependent and Cripto-independent mechanisms. Mol Cell 2001;7:949-957.

8 Oh SP, Yeo CY, Lee Y, et al. Activin type IIA and IIB receptors mediate Gdf11 signaling in axial vertebral patterning. Genes Dev 2002;16:2749-2754.

9 Rebbapragada A, Benchabane $\mathrm{H}$, Wrana JL, et al. Myostatin signals through a transforming growth factor beta-like signaling pathway to block adipogenesis. Mol Cell Biol 2003;23:7230-7242.

$10 \mathrm{Wu} \mathrm{HH}$, Ivkovic S, Murray RC, et al. Autoregulation of neurogenesis by GDF11. Neuron 2003;37:197-207.

11 ten Dijke P, Yamashita H, Ichijo H, et al. Characterization of type I receptors for transforming growth factorbeta and activin. Science 1994;264:101-104.

12 Oh SP, Seki T, Goss KA, et al. Activin receptor-like kinase 1 modulates transforming growth factor-beta 1 signaling in the regulation of angiogenesis. Proc Natl Acad Sci USA 2000;97:2626-2631.

13 Chen YG, Massague J. Smad1 recognition and activation by the ALK1 group of transforming growth factor-beta family receptors. J Biol Chem 1999;274:3672-3677.

14 Lamouille S, Mallet C, Feige JJ, et al. Activin receptorlike kinase 1 is implicated in the maturation phase of angiogenesis. Blood 2002;100:4495-4501.

15 Goumans MJ, Valdimarsdottir G, Itoh S, et al. Balancing the activation state of the endothelium via two distinct TGF-beta type I receptors. EMBO J 2002;21: 1743-1753.

16 Goumans MJ, Valdimarsdottir G, Itoh S, et al. Activin receptor-like kinase (ALK)1 is an antagonistic mediator of lateral TGFbeta/ALK5 signaling. Mol Cell 2003; 12:817-828.

17 Lebrin F, Goumans MJ, Jonker L, et al. Endoglin promotes endothelial cell proliferation and TGF-beta/ ALK1 signal transduction. EMBO J 2004;23:4018-4028.

18 Iseki S, Osumi-Yamashita $\mathrm{N}$, Miyazono $\mathrm{K}$, et al. Localization of transforming growth factor-beta type I and type II receptors in mouse development. Exp Cell Res 1995;219:339-347.

19 Tomoda T, Shirasawa T, Yahagi YI, et al. Transforming growth factor-beta is a survival factor for neonate cortical neurons: coincident expression of type I receptors in developing cerebral cortices. Dev Biol 1996;179:79-90.

20 Zhao Y, Young SL, McIntosh JC, et al. Ontogeny and localization of TGF-beta type I receptor expression during lung development. Am J Physiol Lung Cell Mol Physiol 2000;278:L1231-L1239.

21 Li E, Bestor TH, Jaenisch R. Targeted mutation of the DNA methyltransferase gene results in embryonic lethality. Cell 1992;69:915-926.

22 Seki T, Yun J, Oh SP. Arterial endothelium-specific activin receptor-like kinase 1 expression suggests its role in arterialization and vascular remodeling. Circ Res 2003;93:682-689.

23 Keller A, Margolis FL. Immunological studies of the rat olfactory marker protein. J Neurochem 1975;24: 1101-1106.

24 Margolis FL. Olfactory marker protein (OMP). Scand J Immunol Suppl 1982;9:181-199.

25 Wilkinson DG (ed). In Situ Hybridization: A Practical Approach. IRL Press at Oxford University Press: Oxford, UK, 1992, pp 75-85. 
26 Larsson J, Goumans MJ, Sjostrand LJ, et al. Abnormal angiogenesis but intact hematopoietic potential in TGF-beta type I receptor-deficient mice. EMBO J 2001; 20:1663-1673.

27 Calof AL, Chikaraishi DM. Analysis of neurogenesis in a mammalian neuroepithelium: proliferation and differentiation of an olfactory neuron precursor in vitro. Neuron 1989;3:115-127.

28 Paranya G, Vineberg S, Dvorin E, et al. Aortic valve endothelial cells undergo transforming growth factorbeta-mediated and non-transforming growth factorbeta-mediated transdifferentiation in vitro. Am J Pathol 2001;159:1335-1343.

29 Shalaby F, Rossant J, Yamaguchi TP, et al. Failure of blood-island formation and vasculogenesis in Flk-1deficient mice. Nature 1995;376:62-66.

30 Risau W. Mechanisms of angiogenesis. Nature 1997; 386:671-674.
31 Pepper MS. Transforming growth factor-beta: vasculogenesis, angiogenesis, and vessel wall integrity. Cytokine Growth Factor Rev 1997;8:21-43.

32 Yancopoulos GD, Davis S, Gale NW, et al. Vascularspecific growth factors and blood vessel formation. Nature 2000;407:242-248.

33 Leveen P, Pekny M, Gebre-Medhin S, et al. Mice deficient for PDGF B show renal, cardiovascular, and hematological abnormalities. Genes Dev 1994;8:1875-1887.

34 Soriano P. Abnormal kidney development and hematological disorders in PDGF beta-receptor mutant mice. Genes Dev 1994;8:1888-1896.

35 Folkman J, D'Amore PA. Blood vessel formation: what is its molecular basis? Cell 1996;87:1153-1155.

36 Antonelli-Orlidge A, Saunders KB, Smith SR, et al. An activated form of transforming growth factor beta is produced by cocultures of endothelial cells and pericytes. Proc Natl Acad Sci USA 1989;86:4544-4548. 